\title{
$17 \beta$-estradiol improves hepatic mitochondrial biogenesis and function through PGC1B
}

\author{
Bel M Galmés-Pascual1,2, Antonia Nadal-Casellas', Marco Bauza-Thorbrügge1,2, \\ Miquel Sbert-Roig1,2, Francisco J García-Palmer1,2,3, Ana M Proenza1,2,3, \\ Magdalena Gianotti 1,2,3 and Isabel Lladó1,2,3 \\ 1Departament de Biologia Fonamental i Ciències de la Salut, Grup Metabolisme Energètic i Nutrició, \\ Institut Universitari d'Investigació en Ciències de la Salut (IUNICS), Universitat de les Illes Balears, Palma \\ de Mallorca, Illes Balears, Spain \\ 2Institut d'Investigació Sanitària de Palma (IdISPa), Hospital Universitari Son Espases, Palma de Mallorca, \\ Illes Balears, Spain \\ ${ }^{3}$ Centro de Investigación Biomédica en Red Fisiopatología de la Obesidad y la Nutrición (CIBERobn, \\ CB06/03/0043), Instituto de Salud Carlos III, Madrid, Spain
}

Correspondence should be addressed to M Gianotti

Email

magdalena.gianotti@uib.es

\begin{abstract}
Sexual dimorphism in mitochondrial biogenesis and function has been described in many rat tissues, with females showing larger and more functional mitochondria. The family of the peroxisome proliferator-activated receptor gamma coactivator 1 (PGC1) plays a central role in the regulatory network governing mitochondrial biogenesis and function, but little is known about the different contribution of hepatic PGC1A and PGC1B in these processes. The aim of this study was to elucidate the role of $17 \beta$-estradiol (E2) in mitochondrial biogenesis and function in liver and assess the contribution of both hepatic PGC1A and PGC1B as mediators of these effects. In ovariectomized (OVX) rats (half of which were treated with E2) estrogen deficiency led to impaired mitochondrial biogenesis and function, increased oxidative stress, and defective lipid metabolism, but was counteracted by E2 treatment. In HepG2 hepatocytes, the role of E2 in enhancing mitochondrial biogenesis and function was confirmed. These effects were unaffected by the knockdown of PGC1A, but were impaired when PGC1B expression was knocked down by specific siRNA. Our results reveal a widespread protective role of E2 in hepatocytes, which is explained by enhanced mitochondrial content and oxidative capacity, lower hepatic lipid accumulation, and a reduction of oxidative stress. We also suggest a novel hepatic protective role of PGC1B as a modulator of E2 effects on mitochondrial biogenesis and function supporting activation of PGC1B as a therapeutic target for hepatic mitochondrial disorders.
\end{abstract}

\section{Key Words}

- mitochondrial biogenesis and function

- PGC1

- 17ß-estradiol

- liver

- ovariectomy

- HepG2 cells
Journal of Endocrinology (2017) 232, 297-308

\section{Introduction}

Sexual dimorphism in mitochondrial biogenesis and function has been reported in many rat tissues, pointing to sex hormones as relevant candidates in the modulation thereof. Female rats show larger mitochondria and higher levels of mitochondrial DNA (mtDNA) and mitochondrial respiratory chain proteins, which are consequently 
associated with greater oxidative capacity and increased ATP content in many tissues (Justo et al. 2005a, Stirone et al. 2005, Gómez-Pérez et al. 2008, Guevara et al. 2009, NadalCasellas et al. 2010, 2013, Amengual-Cladera et al. 2012, Gaignard et al. 2015). Research using cell cultures treated with 17 $\beta$-estradiol (E2) also supports these previous findings in rats, denoting a main role of this hormone in modulating mitochondrial biogenesis and function (Chen et al. 1998, Mattingly et al. 2008, CapllonchAmer et al. 2013, 2014, Guo et al. 2013, Sbert-Roig et al. 2016). In postmenoupausal women and in ovariectomized (OVX) rats, estrogen deficiency is associated with body weight gain and abdominal fat deposition (Tchernof et al. 2000, Moreno et al. 2015), hepatic triglyceride accumulation (Völzke et al. 2007, Moreno et al. 2015), and increased insulin resistance (Szmuilowicz et al. 2009). In this same line, men usually show greater hepatic fat accumulation than premenopausal women, a profile that is inverted when the comparison is made with women after menopause (Park et al. 2006). Moreover, increased defense against oxidative stress has also been reported in females of many mammalian species, which may also corroborate a protective role of estrogen (Borrás et al. 2003, 2010, Viña et al. 2005). All in all, estrogen seems to positively influence mitochondrial function and energy homeostasis.
The peroxisome proliferator-activated receptor gamma coactivator-1 (PGC1) family of transcriptional coactivators plays a central role in regulating mitochondrial biogenesis and function (Scarpulla 2011). This regulation is achieved by both PGC1A and PGC1B through coactivation of nuclear respiratory factors 1 (Nrf1) and 2 (Nrf2) and estrogen-related receptor alpha (ERR-alpha) (Wu et al. 1999, Schreiber et al. 2004, Shao et al. 2010). These transcription factors regulate the expression of mitochondrial transcription factor A (Tfam) and mitochondrial subunits of the electron transport chain complex (Wu et al. 1999). PGC1A was originally discovered as a cold-inducible coactivator of adaptive thermogenesis and mitochondrial biogenesis, in both brown adipose tissue and skeletal muscle, where it is abundantly expressed (Puigserver et al. 1998, Liu \& Lin 2011). PGC1A levels in liver are minimal under fed condition but a dramatic increase is observed during fasting and under diabetes, thereby increasing gluconeogenesis, has been reported (Herzig et al. 2001). PGC1B regulates hepatic fatty acid metabolism by controlling gene expression such as those regulating both b-oxidation (Lin et al. 2003) and de novo synthesis of fatty acids (Chambers et al. 2012). In contrast, PGC1B, which shares sequence similarities with PGC1A, is a poor inducer of hepatic gluconeogenic genes (Lin et al. 2003).

Table 1 Oligonucleotide primer sequences and conditions used in real-time PCR amplification in liver and HepG2 hepatocytes.

\begin{tabular}{|c|c|}
\hline Gene & Forward primer $\left(5^{\prime} \rightarrow 3^{\prime}\right)$ \\
\hline Pgc1a (R) & ATCTACTGCCTGGGGACCTT \\
\hline Pgc1b (R) & ACTATGATCCCACGTCTGAAGAGTC \\
\hline Tfam (R) & GCTAAACACCCAGATGCAAAA \\
\hline$N r f 1(\mathrm{R})$ & TTACTCTGCTGTGGCTGATGG \\
\hline mtDNA (R) & TACACGATGAGGCAACCAAA \\
\hline Pepck (R) & GGGGGTGTTTACTGGGAAGG \\
\hline Ppara (R) & TGCCTTCCCTGTGAACTGAC \\
\hline Cpt1a (R) & CGCACATTAGACCGTGAGGA \\
\hline Srebp1c (R) & CGCTACCGTTCCTCTATCAATGAC \\
\hline Gapdh (R) & ACTTTGGCATCGTGGAAGGG \\
\hline PGC1A (H) & САСТССТССТСАTAAAGCCAAC \\
\hline PGC1B (H) & GCTGACAAGAAATAGGAGAGGC \\
\hline TFAM $(\mathrm{H})$ & GTGGTTTTCATCTGTCTTGGC \\
\hline NRF1 $(\mathrm{H})$ & GTAGCCACATTGGCTGATGC \\
\hline $\operatorname{COX} 1(\mathrm{H})$ & TACGTTGTAGCCCACTTCCACT \\
\hline PEPCK $(\mathrm{H})$ & AGCTCAGAGGATGGGGAACC \\
\hline PPARA (H) & CGGTGACTTATCCTGTGGTCC \\
\hline CPT1A $(\mathrm{H})$ & TGGCCTTTCAGTTCACGGTC \\
\hline SREBP1C $(\mathrm{H})$ & TAAGTCTGCGCACTGCTGTC \\
\hline GAPDH $(\mathrm{H})$ & CTGGTGGTCCAGGGGTCTTA \\
\hline
\end{tabular}

\begin{tabular}{l} 
Reverse primer $\left(5^{\prime} \rightarrow 3^{\prime}\right)$ \\
\hline ATGTGTCGCCTTCTTGCTCT \\
CCTTGTCTGAGGTATTGAGGTATTC \\
CGAGGTCTTTTTGGTTTCC \\
CCTCTGATGCTTGCGTCGTCT \\
GGTAGGGGGTGTGTTGTGAG \\
GCGGGGTCAATAATGGGACA \\
GCTTCAAGTGGGGAGAGAGG \\
CCTTGAAGTACCGCCTCTG \\
AGTTTCTGGTTGCTGTGCTGTAAG \\
CCGTTCAGCTCTGGGATGAC \\
GGACTTGCTGAGTTGTGCATA \\
TGAATTGGAATCGTAGTCAGTG \\
ACTCCGCCCTATAAGCATCTTG \\
CTCTGATGCTTGCGTCGTCT \\
GGATAGGCCGAGAAAGTGTTGT \\
CCACAAAGACTCCATGTTGCC \\
CGGTCGCACTTGTCATACAC \\
ACGATAAGCCAACTGGAGGG \\
TGGAAAGGTGAGCCAGCATC \\
CCACTCCTCCACCTTTGACG
\end{tabular}

\begin{tabular}{ccc}
$\begin{array}{c}\text { Annealing } \\
\text { temperature }\left({ }^{\circ} \mathrm{C}\right)\end{array}$ & & $\begin{array}{c}\text { Product } \\
\text { length }(\mathrm{bp})\end{array}$ \\
\cline { 1 - 1 } 60 & & 180 \\
60 & & 152 \\
60 & & 269 \\
55 & & 92 \\
60 & & 162 \\
60 & & 161 \\
60 & & 151 \\
60 & & 184 \\
60 & & 140 \\
60 & & 178 \\
60 & & 190 \\
60 & & 184 \\
60 & & 200 \\
60 & 150 \\
60 & & 189 \\
60 & & 196 \\
60 & & 184 \\
60 & 172 \\
60 & 157 \\
60 & 156
\end{tabular}

Cox1, cytochrome c oxidase subunit 1; Cpt1a, carnitine palmitoyltransferase 1a (liver); Gapdh, Glyceraldehyde 3-phosphate dehydrogenase; H, human; mtDNA, mitochondrial DNA; Nrf1, nuclear respiratory factor 1; Pepck, phosphoenolpyruvate carboxykinase; Pgc1a, peroxisome proliferator-activated receptor coactivator 1a; Pgc1b, peroxisome proliferator-activated receptor coactivator $1 \mathrm{~b}$; Ppara, peroxisome proliferator-activated receptor alpha; $\mathrm{R}$, rat; Srebp1c, sterol regulatory element-binding transcription factor 1c; Tfam, mitochondrial transcription factor A. 
Table 2 Effects of ovariectomy and 17 $\beta$-estradiol replacement on body and liver weights, liver composition and serum levels of estradiol and insulin.

\begin{tabular}{|c|c|c|c|c|}
\hline & Control & ovx & OVX + E2 & ANOVA \\
\hline BW (g) & $218 \pm 5$ & $298 \pm 6^{a}$ & $242 \pm 5^{a, b}$ & $\mathrm{H}$ \\
\hline $\begin{array}{l}\text { Liver weight } \\
\text { (g) }\end{array}$ & $5.84 \pm 0.11$ & $6.64 \pm 0.17^{a}$ & $6.08 \pm 0.16^{b}$ & $\mathrm{H}$ \\
\hline $\begin{array}{l}\mathrm{TG}(\mathrm{mg} / \mathrm{g} \\
\text { tissue) }\end{array}$ & $20.9 \pm 0.5$ & $24.2 \pm 0.6^{a}$ & $19.6 \pm 0.6^{b}$ & $\mathrm{H}$ \\
\hline E2 (\%) & $100 \pm 24$ & $61.3 \pm 9.7$ & $240 \pm 103^{a, b}$ & $\mathrm{H}$ \\
\hline Insulin (ng/mL) & $0.40 \pm 0.01$ & $0.51 \pm 0.04 a$ & $0.40 \pm 0.02^{b}$ & $\mathrm{H}$ \\
\hline
\end{tabular}

Values are mean \pm s.E.M. of six animals per group. Hormone effect is analyzed by one-way ANOVA $(P<0.05): \mathrm{H}$ indicates hormone effect. Least significant difference (LSD) is applied as a post hoc analysis of hormone effect $(P<0.05)$.

aSignificant difference from control. bSignificant difference from OVX. BW, body weight; E2, 17 $\beta$-estradiol; OVX, ovariectomized; OVX+E2, OVX treated with 17 $\beta$-estradiol; TG, triglyceride.

The aim of the present study was to clarify the contribution of E2 to the differences observed in hepatic mitochondrial biogenesis and function between male and female rats. Furthermore, the involvement of both PGC1A and PGC1B were assessed as mediators of these effects. To accomplish this, studies were performed in vivo using OVX rats with $\mathrm{E} 2$ replacement, which were combined with in vitro studies silencing $P G C 1 A$ or $P G C 1 B$ in HepG2 cells treated with E2.

\section{Materials and methods}

\section{Animals and treatments}

Animal experiments were performed in accordance with general guidelines approved by EU regulations (2010/63/UE) and our institutional ethics committee. Wistar female rats both control $(n=6)$ and OVX $(n=12)$ were purchased from Charles River, where OVX rats had been ovariectomized or sham operated at 5 weeks of age to suppress endogenous ovarian steroid production. Animals were kept in a controlled environment of $22^{\circ} \mathrm{C}$ and $65 \pm 3 \%$ humidity on a 12-h light-darkness cycle with free access to water and pelleted standard diet (A04, SAFE, Paris, France). At ten weeks of age, OVX rats were divided into two experimental groups: OVX $(n=6)$ and OVX treated with $\mathrm{E} 2(\mathrm{OVX}+\mathrm{E} 2)(n=6)$. OVX $+\mathrm{E} 2$ rats
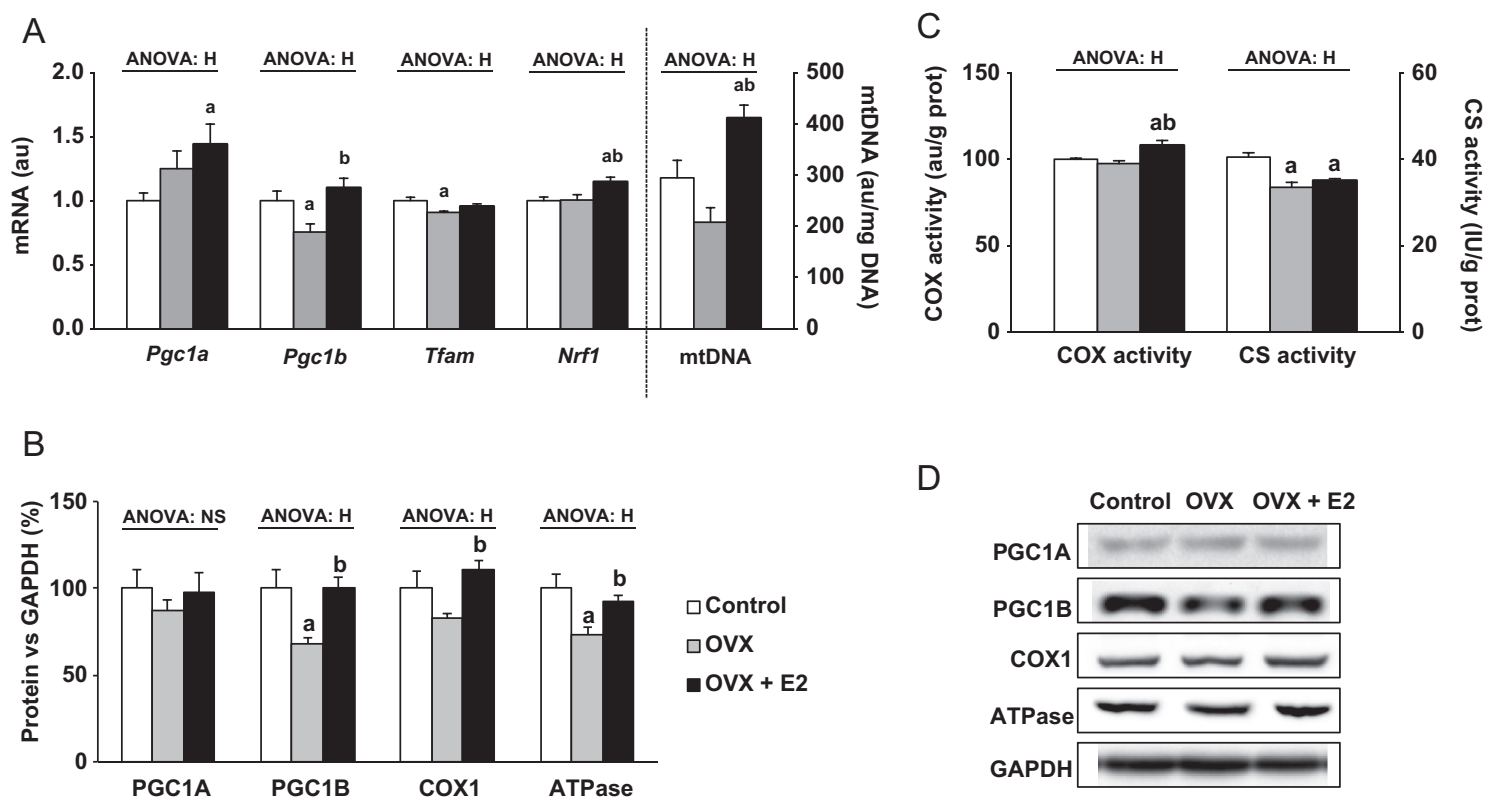

\section{Figure 1}

Effects of ovariectomy and 17 $\beta$-estradiol replacement on markers of mitochondrial biogenesis and function in liver. mRNA and mtDNA levels (A), protein levels (B), COX and CS activity (C), and representative Western blots for corresponding proteins (D). GenEx software was used to analyze the $C_{t}$ values normalized to Gapdh $C_{\mathrm{t}}$. Protein levels were normalized to GAPDH intensity. Values of control group for protein levels and COX activity were set as 100 and for mRNA levels were set as 1. OVX, ovariectomized; OVX+E2, OVX treated with 17 $\beta$-estradiol; PGC1A, peroxisome proliferator-activated receptor coactivator 1A; PGC1B, peroxisome proliferator-activated receptor coactivator 1B; Tfam, mitochondrial transcription factor A; Nrf1, nuclear respiratory factor 1; mtDNA, mitochondrial DNA; COX1, cytochrome c oxidase subunit 1; COX, cytochrome c oxidase; CS, citrate synthase. Values are mean \pm s.E.M. of six animals per group. Hormone effect is analyzed by one-way ANOVA $(P<0.05): \mathrm{H}$ indicates hormone effect. Least significant difference (LSD) is applied as a post hoc analysis of hormone effect $(P<0.05)$. aSignificant difference from control. bSignificant difference from OVX.

http://joe.endocrinology-journals.org

DOI: 10.1530/JOE-16-0350
() 2017 Society for Endocrinology Printed in Great Britain
Published by Bioscientifica Ltd 
were given a subcutaneous injection of $10 \mu \mathrm{g} / \mathrm{kg}$ of E2 dissolved in corn oil (vehicle) every $48 \mathrm{~h}$ for 4 weeks prior to killing, whereas OVX group was treated only with the vehicle. The estrous cycle was regularly determined by measuring vaginal wall impedance with the estrous cycle monitor Impeast (Cibertec, Madrid, Spain) and confirmed by microscopic examination of fresh vaginal smears, so all the control animals were in the diestrous
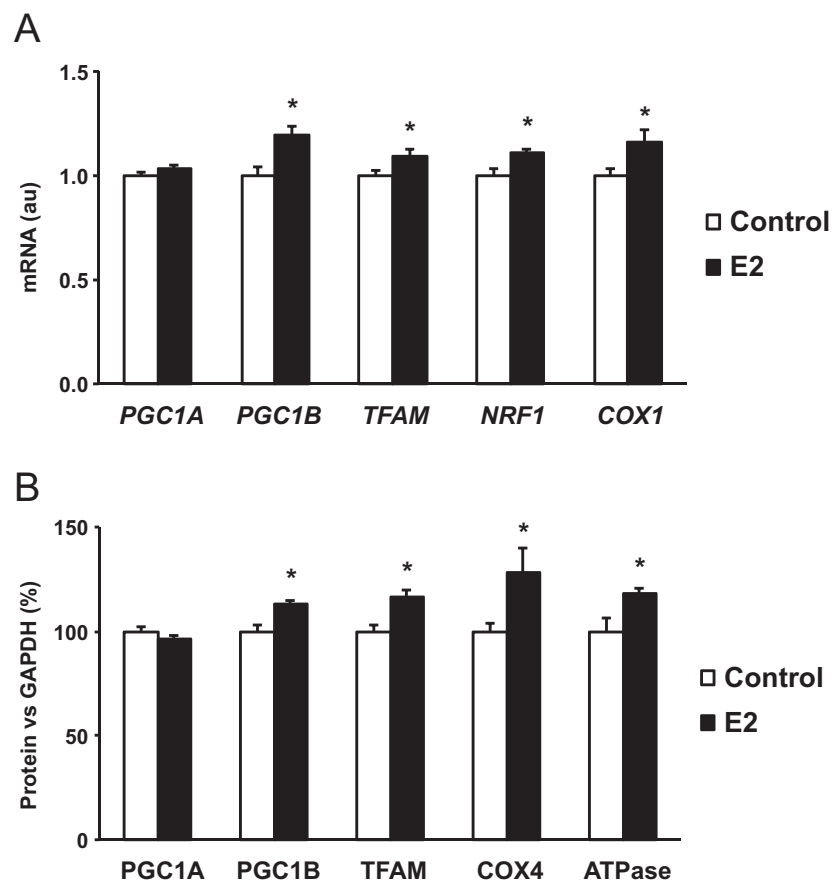

C

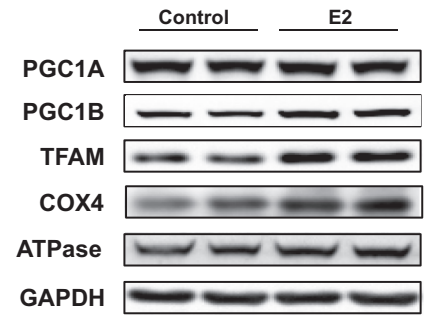

Figure 2

Effects of $17 \beta$-estradiol on markers of mitochondrial biogenesis and function in HepG2 cells. mRNA (A) and protein (B) levels, and representative Western blots for corresponding proteins (C). GenEx software was used to analyze the $C_{\mathrm{t}}$ values normalized to Gapdh $C_{\mathrm{t}}$. Protein levels were normalized to GAPDH intensity. Values of control group for protein levels were set as 100 and for mRNA levels were set as 1. Cells were treated with E2 $(10 \mathrm{nM})$ for $40 \mathrm{~h}$. Control cells were administered the equivalent volume of vehicle (ethanol). PGC1B, peroxisome proliferator-activated receptor coactivator $1 \mathrm{~B} ; \mathrm{PGC1A}$, peroxisome proliferator-activated receptor coactivator 1A; TFAM, mitochondrial transcription factor $\mathrm{A}$; Nrf1, nuclear respiratory factor 1 ; Cox1, cytochrome c oxidase subunit $1 ; \operatorname{COX} 4$, cytochrome $c$ oxidase subunit 4 . Values are mean \pm S.E.M. of three independent experiments performed in duplicate $(n=6)$. Statistically significant differences were determined using Student's $t$-test $(P<0.05)$. *Significant difference from control. phase at the time they were killed. At 14 weeks of age and after a 12-h period of fasting, rats were killed by decapitation. Trunk blood was collected and the liver was rapidly removed and weighed, and a piece was frozen at $-80^{\circ} \mathrm{C}$ until analysis. Serum levels of $\mathrm{E} 2$ and insulin were determined by ELISA kits provided by DRG Instruments (Marburg, Germany) and Mercodia (Uppsala, Sweden), respectively. Before $\mathrm{E} 2$ analysis, the serum organic fraction was concentrated using a sample extraction procedure (Dighe \& Sluss 2004).

\section{Hepatic homogenate preparation and determinations}

Fresh liver was homogenized with a disperser (IKA T10 basic ULTRA-TURRAX) in a proportion of $0.1 \mathrm{~g}$ in $1 \mathrm{~mL}$ STE buffer (250 mM sucrose, $20 \mathrm{mM}$ Tris- $\mathrm{HCl}, 40 \mathrm{mM} \mathrm{KCl}$, $2 \mathrm{mM}$ EDTA, $\mathrm{pH} 7.4$ ) and immediately used to assay the activities of cytochrome c oxidase (COX) (ChrzanowskaLightowlers et al. 1993), citrate synthase (CS) (Nakano et al. 2005), and superoxide dismutase (SOD) (Quick et al. 2000) by spectrophotometric methods. Hepatic triglycerides were measured spectrophotometrically using a commercial kit (Spinreact, Girona, Spain). The remaining volume was stored at $-20^{\circ} \mathrm{C}$ with phosphatase and protease inhibitors $(1 \mathrm{mM}$ sodium orthovanadate, $1 \mathrm{mM}$ PMSF, $10 \mu \mathrm{M}$ leupeptin and $10 \mu \mathrm{M}$ pepstatin) until analysis. Protein carbonyl groups, an index of protein oxidation, were determined in the homogenates by immunoblotting using the OxiSelect Protein Carbonyl Immunoblot Kit (Cell Biolabs, San Diego, CA, USA) according to the manufacturer's protocol. Isolation and

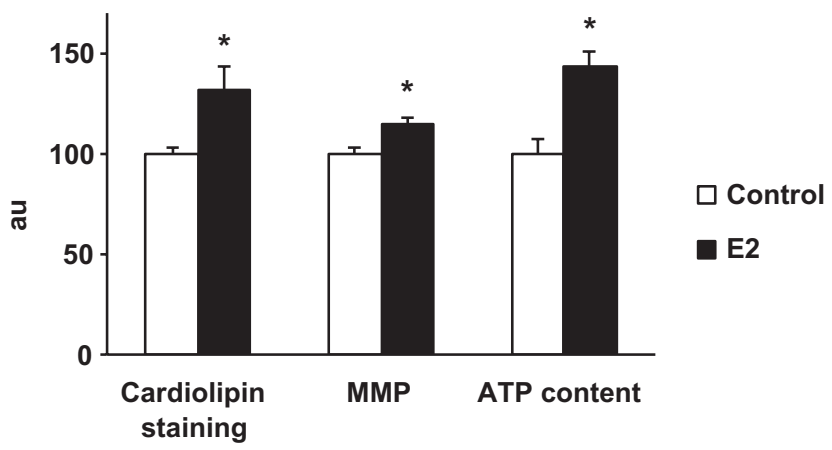

Figure 3

Effects of $17 \beta$-estradiol on mitochondrial mass (A), mitochondrial membrane potential (B), and ATP content (C) in HepG2 cells. All values were normalized per number of viable cells and values for control group were set as 100 . Cells were treated with E2 $(10 \mathrm{nM})$ for $40 \mathrm{~h}$. Control cells were administered the equivalent volume of vehicle (ethanol). MMP, mitochondrial membrane potential. Values are mean \pm S.E.M. $(n=8)$. Statistically significant differences were determined using Student's $t$-test $(P<0.05)$. *Significant difference from control.

Published by Bioscientifica Ltd 
semi-quantification of mtDNA, an index of mitochondrial content, was carried out in tissue homogenates as previously described (Justo et al. 2005b). Briefly, real-time PCR was performed to amplify the mitochondrial gene NADH dehydrogenase subunit 4 , which is exclusive of mtDNA. The oligonucleotide sequences and annealing step conditions used in real-time PCR are detailed in Table 1. RNA was obtained using TriPure Isolation Reagent (Roche Diagnostics).

\section{HepG2 cell culture}

Human hepatocellular carcinoma cell line HepG2 (American Type Culture Collection, Manassas, USA) was routinely maintained at $37^{\circ} \mathrm{C}$ in a humidified atmosphere of $5 \% \mathrm{CO}_{2}$ in MEM containing $5.6 \mathrm{mM}$ glucose (Biowest, Nuaillé, France), supplemented with $10 \%$ fetal bovine serum (FBS) and 1\% penicillin-streptomycin, from Biowest and Biological Industries (Beit-Haemek, Israel), respectively. All experiments were conducted between sixth and twelfth passages. Cells were seeded in six well plates until $70 \%$ confluence and then the medium was replaced $24 \mathrm{~h}$ before treatment by phenol red-free MEM $5.6 \mathrm{mM}$ glucose (Biological Industries) supplemented with $10 \%$ charcoal-stripped FBS (Biological Industries) and 1\% penicillin-streptomycin (Biowest). Afterward, cells were treated with $10 \mathrm{nM} \mathrm{E} 2$ or the vehicle (ethanol) for $40 \mathrm{~h}$. Preliminary experiments were carried out to determine the appropriate concentration of each compound, and cell death was assessed in 96 well plates using crystal violet nuclear staining assay (Nagamine et al. 2009). Briefly, cells were stained with $0.5 \%(\mathrm{p} / \mathrm{v})$ crystal violet in

Table 3 Effects of ovariectomy and 17 $\beta$-estradiol replacement on oxidative stress markers in liver.

\begin{tabular}{|c|c|c|c|c|}
\hline & Control & ovx & OVX +E2 & ANOVA \\
\hline $\begin{array}{l}\text { SOD (IU/g } \\
\text { protein) }\end{array}$ & $10.0 \pm 0.3$ & $8.25 \pm 0.46^{a}$ & $12.9 \pm 1.2^{a, b}$ & $\mathrm{H}$ \\
\hline HNE (au) & $100 \pm 5$ & $124 \pm 4^{a}$ & $115 \pm 2^{a}$ & $\mathrm{H}$ \\
\hline $\begin{array}{l}\text { Protein carbonyl } \\
\text { groups (au) }\end{array}$ & $100 \pm 6$ & $129 \pm 11$ & $77 \pm 19 b$ & $\mathrm{H}$ \\
\hline
\end{tabular}

SOD activity is expressed as international units $(\mu \mathrm{mol} / \mathrm{min})$. Protein levels were normalized to GAPDH intensity. Values for control group were set as 100 for the determination of $4 \mathrm{HNE}$ and protein carbonyl groups. Values are mean \pm s.E.M. of six animals per group. Hormone effect is analyzed by one-way ANOVA $(P<0.05)$ : $\mathrm{H}$ indicates hormone effect. Least significant difference (LSD) is applied as a post hoc analysis of hormone effect $(P<0.05)$. aSignificant difference from control. bSignificant difference from $O V X$. $\mathrm{OVX}$, ovariectomized; OVX+E2, OVX treated with 17 $\beta$-estradiol; SOD, superoxide dismutase; HNE, 4-hydroxynonenal.
$30 \%(\mathrm{v} / \mathrm{v})$ acetic acid for $10 \mathrm{~min}$. After washing, the dye was solubilized in $100 \mu \mathrm{L}$ methanol and absorbance was measured photometrically at $595 \mathrm{~nm}$ to determine cell viability. RNA and protein were obtained using TriPure Isolation Reagent (Roche Diagnostics).

\section{Gene silencing}

HepG2 cells were reverse transfected with human PGC1A or $P G C 1 B$ siRNA, or with negative control siRNA (Santa Cruz Biotechnology) using Lipofectamine RNAiMAX (Thermo Fisher Scientific) according to the manufacturer's instructions. In short, $20 \mathrm{nM}$ of siRNA was mixed with Lipofectamine RNAiMAX in Opti-MEM reduced serum media (Thermo Fisher) in 12 well plates for $20 \mathrm{~min}$ at room temperature. HepG2 cells were resuspended in complete phenol red-free MEM without antibiotics, counted, and plated into the 12 well plates at the same cell number per well after the $20 \mathrm{~min}$. After $24 \mathrm{~h}$ the transfection mix was removed and cells were treated with E2 (10nM) or ethanol for another $40 \mathrm{~h}$ and then RNA and protein were collected using TriPure Isolation Reagent (Roche Diagnostics) according to the manufacturer's instructions. Cell viability was measured in 96 well plates by crystal violet nuclear staining assay (Nagamine et al. 2009).

\section{Western blot analysis}

About 30-40 $\mu$ g protein from the hepatic homogenates or $20 \mu \mathrm{g}$ from HepG2 cells were fractioned using SDSPAGE (10-12\% acrylamide) and electrotransferred onto a nitrocellulose membrane. The membranes were blocked

Table 4 Effects of ovariectomy and $17 \beta$-estradiol replacement on mRNA levels of markers of glucose and lipid metabolism in liver.

\begin{tabular}{|c|c|c|c|c|}
\hline & Control & ovx & OVX + E2 & ANOVA \\
\hline Pepck (au) & $1.00 \pm 0.03$ & $1.58 \pm 0.11^{a}$ & $1.14 \pm 0.09 \mathrm{~b}$ & $\mathrm{H}$ \\
\hline Ppara (au) & $1.00 \pm 0.07$ & $0.99 \pm 0.10$ & $1.38 \pm 0.05^{a, b}$ & $\mathrm{H}$ \\
\hline Cpt1a (au) & $1.00 \pm 0.11$ & $1.75 \pm 0.05^{a}$ & $1.59 \pm 0.04^{a}$ & $\mathrm{H}$ \\
\hline Srebp1c (au) & $1.00 \pm 0.08$ & $1.46 \pm 0.08^{a}$ & $0.88 \pm 0.15^{b}$ & $\mathrm{H}$ \\
\hline
\end{tabular}

GenEx software was used to analyze the $C_{\mathrm{t}}$ values normalized to Gadph $C_{\text {t. }}$ Values of control group were set as 1 . Values are mean \pm S.E.M. of six animals per group. Hormone effect is analyzed by one-way ANOVA $(P<0.05): \mathrm{H}$ indicates hormone effect. Least significant difference (LSD) is applied as a post hoc analysis of hormone effect $(P<0.05)$.

aSignificant difference from control. bSignificant difference from OVX. OVX, ovariectomized; OVX+E2, OVX treated with $17 \beta$-estradiol; Pepck phosphoenolpyruvate carboxykinase; Ppara, peroxisome proliferatoractivated receptor alpha; Cpt1a, carnitine palmitoyltransferase 1a (liver); Srebp1c, sterol regulatory element-binding transcription factor $1 c$.

Published by Bioscientifica Ltd. 
(5\% non-fat powdered milk in TBS, pH 7.5, containing 0.05\% Tween 20) and incubated with the corresponding primary antibody. Antibodies against GAPDH (37 kDa), PGC1A (90kDa), and 4-hydroxynoneal (HNE; used as a lipid oxidative damage marker) were supplied by Santa Cruz Biotechnology; antibodies against PGC1B $(113 \mathrm{kDa})$, COX subunit $1(37 \mathrm{kDa})$, and ATPase subunit alpha $(53 \mathrm{kDa})$ were purchased from Abcam; antibody against TFAM $(24 \mathrm{kDa})$ was supplied by Cell Signaling; and antibody against COX subunit $4(16 \mathrm{kDa})$ was from MitoScience (Eugene, OR, USA). Development of immunoblots was performed using Clarity Western Chemiluminescence kit (Bio-Rad). Protein bands were detected using the ChemiDoc XRS System (Bio-Rad) and analyzed using the image analysis program Quantity One (Bio-Rad). Precision Plus Protein Dual Color Standard (Bio-Rad) was used as a molecular weight marker. The band density of each protein was quantified in relation to the loading control (GAPDH).

\section{Analysis of gene expression}

About $1 \mu \mathrm{g}$ RNA was reverse transcribed to cDNA using $25 \mathrm{U} \mathrm{MuLV}$ reverse transcriptase in $10 \mu \mathrm{L}$ retrotranscription mixture $(10 \mathrm{mM}$ Tris- $\mathrm{HCl} \mathrm{pH} 9.0$, $50 \mathrm{mM} \mathrm{KCl}, 0.1 \%$ Triton X-100, $2.5 \mathrm{mM} \mathrm{MgCl}_{2}, 2.5 \mathrm{mM}$ random hexamers, $10 \mathrm{U}$ RNase inhibitor, and $500 \mathrm{mM}$ of each dNTP) for $60 \mathrm{~min}$ at $42^{\circ} \mathrm{C}$ in a GeneAmp 9700 thermal cycler (Applied Biosystems). cDNA solutions were diluted with RNase-free water to a final volume of $100 \mu \mathrm{L}$, and aliquots were frozen at $-20^{\circ} \mathrm{C}$ until analyzed. Real-time PCR was performed using

Table 5 Effects of $17 \beta$-estradiol on mRNA levels of markers of glucose and lipid metabolism in HepG2 cells.

\begin{tabular}{|c|c|c|}
\hline & Control & E2 \\
\hline PEPCK (au) & $1.00 \pm 0.03$ & $0.87 \pm 0.02^{a}$ \\
\hline PPARA (au) & $1.00 \pm 0.05$ & $1.13 \pm 0.04^{a}$ \\
\hline CPT1A (au) & $1.00 \pm 0.04$ & $1.13 \pm 0.03^{a}$ \\
\hline SREBP1C (au) & $1.00 \pm 0.03$ & $0.95 \pm 0.03$ \\
\hline
\end{tabular}

GenEx software was used to analyze the $C_{\mathrm{t}}$ values normalized to Gapdh $C_{\mathrm{t}}$. Values of control group were set as 1. Cells were treated with E2 $(10 \mathrm{nM})$ for $40 \mathrm{~h}$. Control cells were administered the equivalent volume of vehicle (ethanol). Values are mean \pm s.E.M. of three independent experiments performed in duplicate $(n=6)$. Statistically significant differences were determined using Student's $t$-test $(P<0.05)$. asignificant difference from control.

PEPCK, phosphoenolpyruvate carboxykinase; PPARA, peroxisome proliferator-activated receptor alpha; CPT1A, carnitine palmitoyltransferase 1a (liver); SREBP1C, sterol regulatory elementbinding transcription factor $1 \mathrm{c}$.
LightCycler 480 SYBR Green I Master Technology in a LightCycler 480 System II rapid thermal cycler (Roche Diagnostics). Each reaction contained $5 \mu \mathrm{L}$ LightCycler 480 SYBR Green I master (containing FastStart Taq DNA polymerase, dNTP mix, reaction buffer, $\mathrm{MgCl}_{2}$, and SYBR Green I dye), sense and antisense primers $(0.374 \mu \mathrm{M}$ each), and $2.5 \mu \mathrm{L}$ cDNA dilution in a final volume of $10 \mu \mathrm{L}$. The amplification program consisted of a pre-incubation step for denaturation of template DNA $\left(95^{\circ} \mathrm{C}, 2 \mathrm{~min}\right)$, followed by 40 cycles consisting of a denaturation $\left(95^{\circ} \mathrm{C}, 5 \mathrm{~min}\right)$, annealing (primerdependent temperature, $10 \mathrm{~s}$ ), and extension steps $\left(72^{\circ} \mathrm{C}, 12 \mathrm{~s}\right)$. The oligonucleotide sequences and annealing step conditions used in real-time PCR are detailed in Table 1. After each cycle, fluorescence was measured at $72^{\circ} \mathrm{C}$. Product specificity was confirmed in initial experiments by agarose gel electrophoresis and routinely by melting curve analysis.

\section{Measurement of mitochondrial mass, mitochondrial membrane potential and ATP content in HepG2 cells}

For all determinations, HepG2 cells were seeded in 96 well plates and treated with E2 as previously described. Values were normalized per number of viable cells determined by crystal violet nuclear staining assay (Nagamine et al. 2009). Mitochondrial mass was assessed using the fluorescent probe $N$-nonyl acridine orange (NAO) as it specifically stains mitochondrial phospholipid cardiolipin (Petit et al. 1992). Briefly,

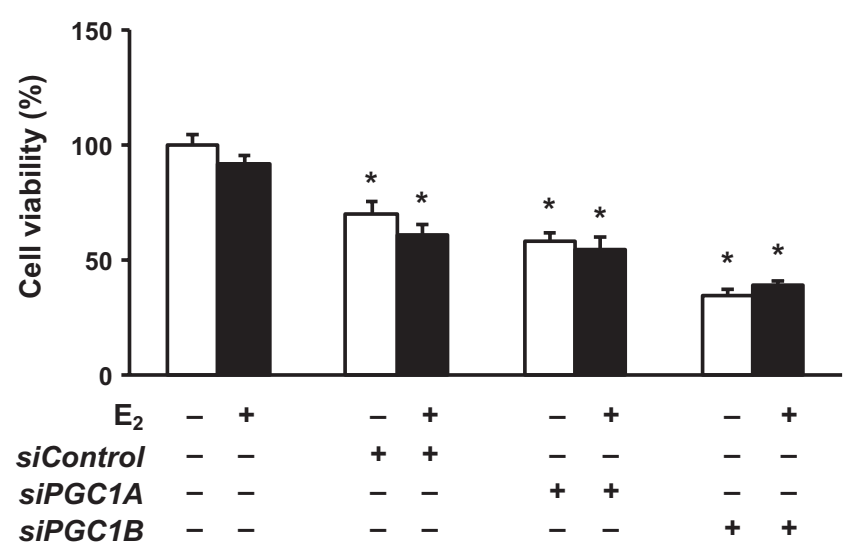

Figure 4

Cell viability in HepG2 cells treated with E2 (10nM) or silenced with specific siRNA (20nM). Values for control group were set as $100 \%$. $P G C 1 A$, peroxisome proliferator-activated receptor coactivator $1 \mathrm{~A}$; $P G C 1 B$, peroxisome proliferator-activated receptor coactivator 1B. Values are mean \pm S.E.M. $(n=8)$. Statistically significant differences were determined using Student's $t$-test $(P<0.05)$. *Significant difference from control (first bar).

Published by Bioscientifica Ltd. 

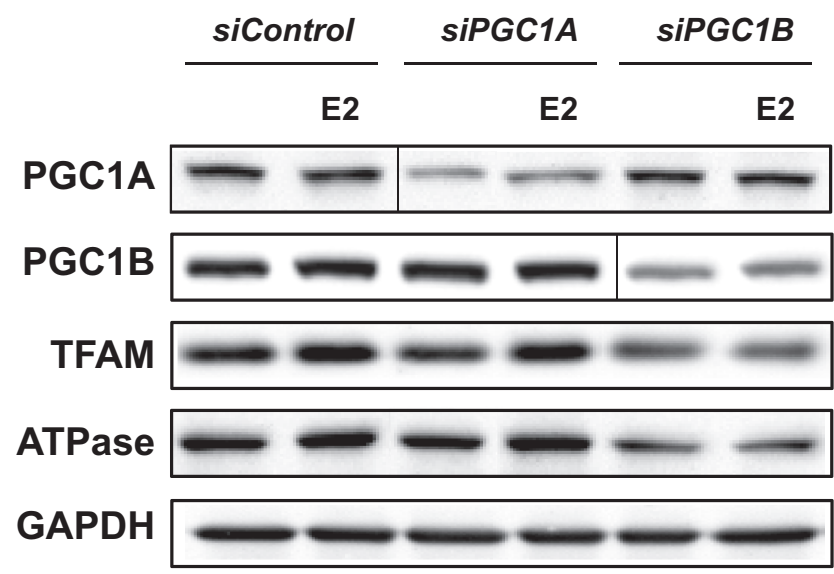

Figure 5

Representative Western blots for corresponding proteins from silencing experiments. $P G C 1 A$, peroxisome proliferator-activated receptor coactivator $1 A ; P G C 1 B$, peroxisome proliferator-activated receptor coactivator 1B; TFAM, mitochondrial transcription factor $A$.

$0.5 \mu \mathrm{M}$ NAO were added to HepG2 cells for $30 \mathrm{~min}$ at $37^{\circ} \mathrm{C}$ in darkness and fluorescence measurement was performed in a FLx800 microplate fluorescence reader (Bio-Tek) with excitation at $485 \mathrm{~nm}$ and emission at $528 \mathrm{~nm}$. Mitochondrial membrane potential (MMP) was tested using tetramethylrhodamine methylester (TMRM) as a lipophilic cationic dye that accumulates within mitochondria according to the membrane potential (Scaduto \& Grotyohann 1999). Cells were dyed with $0.5 \mu \mathrm{M}$ of TMRM for $15 \mathrm{~min}$ at $37^{\circ} \mathrm{C}$ in darkness and fluorescence intensity was measured with excitation at $552 \mathrm{~nm}$ and emission at $576 \mathrm{~nm}$. Finally, ATP was measured with an ATP bioluminescent assay kit (BioVision) following the manufacturer's instructions.

\section{Statistical analysis}

All data from in vivo experiments are expressed as the mean \pm S.E.M. of six animals per group. The effects of ovariectomy and E2 supplementation (hormone effect) were analyzed by one-way ANOVA. Least significant difference (LSD) was applied as a post hoc analysis when hormone effect was present. In vitro data from cell viability, cardiolipin levels, MMP, and ATP content are expressed as mean \pm S.E.M. $(n=8)$ and statistical differences were assessed by Student's t-test. In vitro data from silencing experiments were analyzed from three independent experiments carried out in duplicate $(n=6)$ and statistical differences were assessed by Student's $t$-test. All statistical analyses were performed using a statistical software package (SPSS 20.0 for Mac OSX), and a $P$ value $<0.05$ was considered statistically significant.
$C_{\mathrm{t}}$ values of real-time PCR were analyzed using GenEx Standard Software 5.3.6 (MultiD Analyses, Goteborg, Sweden), and the efficiency of the reaction was taken into account for each gene.
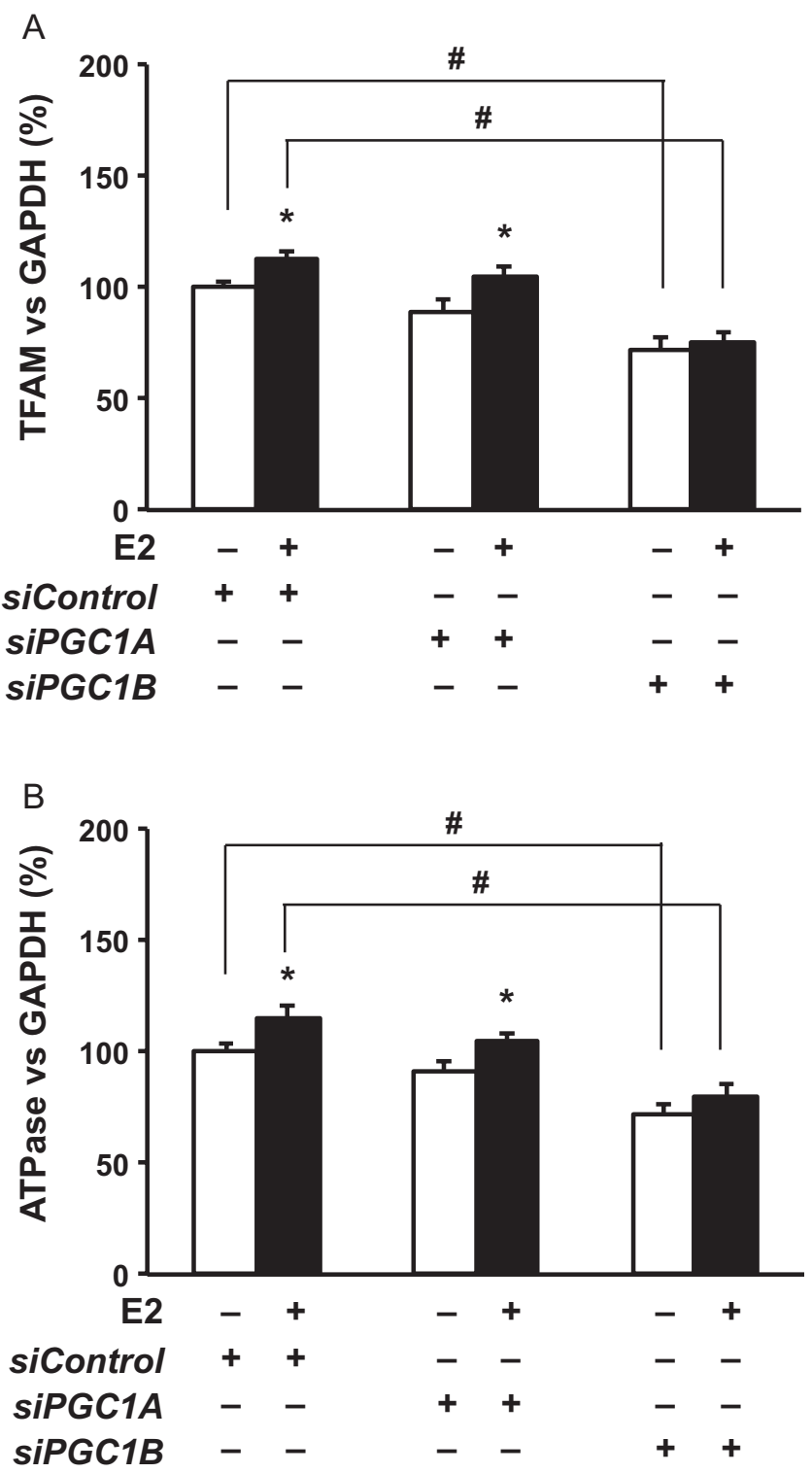

Figure 6

Protein levels of TFAM (A) and ATPase (B) after silencing by specific siRNA in HepG2 cells. Protein levels were normalized to GAPDH intensity and values of control group were set as 100 . Cells were silenced using $20 \mathrm{nM}$ of specific siRNA for $24 \mathrm{~h}$ and subsequently either treated with E2 (10 nM) or left untreated for another $40 \mathrm{~h}$. PGC1A, peroxisome proliferatoractivated receptor coactivator 1a; $P G C 1 B$, peroxisome proliferatoractivated receptor coactivator $1 \mathrm{~b}$; TFAM, mitochondrial transcription factor A. Values are mean \pm s.E.M. of three independent experiments performed in duplicate $(n=6)$. Statistically significant differences were determined using Student's $t$-test $(P<0.05)$. *Significant difference from E2 control. "Significant difference from siControl.

Published by Bioscientifica Ltd. 
Table 6 mRNA and protein levels of PGC1A and PGC1B after silencing by specific siRNA in HepG2 cells.

\begin{tabular}{|c|c|c|c|c|}
\hline & & Control siRNA & Pgc1a siRNA & Pgc1b siRNA \\
\hline \multirow[t]{2}{*}{ PGC1A mRNA levels (au) } & $-E 2$ & $1.00 \pm 0.02$ & $0.66 \pm 0.02^{b}$ & $0.94 \pm 0.02$ \\
\hline & $+\mathrm{E} 2$ & $0.99 \pm 0.07$ & $0.65 \pm 0.03^{b}$ & $0.91 \pm 0.04$ \\
\hline \multirow[t]{2}{*}{ PGC1A protein levels (vs GAPDH) } & $-E 2$ & $100 \pm 1.35$ & $65.8 \pm 9.27 \mathrm{~b}$ & $93.4 \pm 10.7$ \\
\hline & $+E 2$ & $96.6 \pm 6.97$ & $57.0 \pm 3.43^{b}$ & $86.0 \pm 14.1$ \\
\hline \multirow[t]{2}{*}{ PGC1B mRNA levels (au) } & $-E 2$ & $1.00 \pm 0.03$ & $1.04 \pm 0.01$ & $0.65 \pm 0.05^{b}$ \\
\hline & $+\mathrm{E} 2$ & $1.22 \pm 0.05^{a}$ & $1.16 \pm 0.03^{a}$ & $0.88 \pm 0.02^{a, b}$ \\
\hline \multirow[t]{2}{*}{ PGC1B protein levels (vs GAPDH) } & $-E 2$ & $100 \pm 2.38$ & $82.5 \pm 11.7$ & $48.4 \pm 4.37^{b}$ \\
\hline & $+\mathrm{E} 2$ & $119 \pm 6.80^{a}$ & $117 \pm 4.30^{a}$ & $71.1 \pm 10.2^{a, b}$ \\
\hline
\end{tabular}

GenEx software was used to analyze the $C_{t}$ values normalized to Gapdh $C_{t}$ and protein levels were normalized to GAPDH intensity. Values of control group for mRNA levels were set as 1 and for protein levels as 100 . Cells were silenced using $20 \mathrm{nM}$ of specific siRNA for $24 \mathrm{~h}$ and subsequently either treated with E2 $(10 \mathrm{nM})$ or left untreated for another $40 \mathrm{~h}$. Values are mean \pm S.E.M. of three independent experiments performed in duplicate $(n=6)$. Statistically significant differences were determined using Student's $t$-test $(P<0.05)$.

aSignificant difference from E2 control. bSignificant difference from siControl.

PGC1A, peroxisome proliferator-activated receptor coactivator 1A; PGC1B, peroxisome proliferator-activated receptor coactivator 1B.

\section{Results}

\section{Effects of ovariectomy and E2 replacement on body and liver weights, hepatic triglycerides and serum levels of E2 and insulin}

Body and liver weights as well as hepatic triglycerides increased in OVX rats (Table 2). E2 replacement resulted in a decrease of these parameters, but only body weight remained higher than that of controls. Ovariectomy decreased E2 serum levels and E2 treatment increased the levels of this hormone. Ovarian withdrawal increased serum levels of insulin, while E2 replacement restored control values.

\section{Effects of ovariectomy and E2 replacement on markers of mitochondrial biogenesis and function in liver and HepG2 cells}

Ovariectomy induced an impairment of mitochondrial biogenesis and function, assessed by lower PGC1B, TFAM and ATPase mRNA or protein levels (Fig. 1A and B). The OVX group supplemented with E2 exhibited increased levels of markers of mitochondrial biogenesis and function, such as PGC1B, NRF1, COX1 and ATPase mRNA or protein levels. PGC1A protein levels were not modified under any condition, although mRNA levels rose with E2 administration. mtDNA levels increased in response to $\mathrm{E} 2$ treatment compared with control and OVX rats, but the decrease with ovariectomy did not reach statistical significance $(P=0.077)$ (Fig. 1A). COX activity was not altered by ovariectomy but E2 administration enhanced it, whereas ovarian withdrawal diminished CS activity and E2 administration did not restore control values (Fig. 1C).
Accordingly, protein and mRNA levels of PGC1B were enhanced in HepG2 cells in response to E2 treatment, while PGC1A did not suffer any modification (Fig. 2A and B). TFAM, NRF1, COX1, COX4 and ATPase mRNA or protein levels also rose with E2 treatment. Furthermore, E2-treated HepG2 cells exhibited higher mitochondrial mass and MMP as well as upper levels of ATP content (Fig. 3).

\section{Effects of ovariectomy and E2 replacement on oxidative stress markers in liver}

Ovariectomy was associated with decreased SOD activity, which was increased with E2 replacement even in comparison with control rats (Table 3). Lipid peroxides (HNE) rose with ovariectomy, although E2 treatment did not fully revert this condition. Although levels of carbonyl groups (a marker of protein damage) did not increase with ovariectomy, E2 administration led to a significant reduction compared with OVX group.

\section{Effects of ovariectomy and E2 replacement on glucose and lipid metabolism markers in liver and HepG2 cells}

Concomitant with hormone withdrawal, phosphoenolpyruvate carboxykinase (Pepck) mRNA levels rose, whereas E2 supplementation restored them to control values (Table 4). Both carnitine palmitoyltransferase 1a (Cpt1a) and sterol regulatory element-binding transcription factor 1c (Srebp1c) were increased with ovariectomy. E2 treatment restored only Srebp1c to control values. Gene expression of peroxisome proliferator-activated receptor alpha (Ppara) increased with E2 replacement in comparison with control and OVX rats.

Published by Bioscientifica Ltd 
In HepG2 cells, E2 treatment led to a decrease in PEPCK expression, while mRNA levels of both PPARA and CPT1A were increased (Table 5). SREBP1C was not altered by E2.

\section{Effects of PGC1A or PGC1B knockdown and E2 treatment on markers of mitochondrial biogenesis and function}

Cell viability was assessed in silencing experiments, showing that transfection with control siRNA or Pgc1a decreased viability by $30-40 \%$ compared to nontransfected hepatocytes whereas $P g c 1 b$ knockdown significantly decreased cell viability by $65 \%$ (Fig. 4).

$P G C 1 A$ and $P G C 1 B$ inhibition by siRNA was determined by measuring mRNA and protein levels after transfection and treatment with E2 (Fig. 5 and Table 6). siRNA specifically knocked down its target genes by 34-50\% compared to hepatocytes transfected with a nontarget siRNA, both for mRNA and protein levels. Silencing efficiency was not statistically different between both $P G C 1 A$ and $P G C 1 B$ knockdown.

HepG2 cells treated with siRNA targeting PGC1B reduced TFAM and ATPase levels by $25 \%$ compared to basal conditions and remained lower with E2 treatment (Figs 5 and 6). PGC1A downregulation did not produce a reduction of these parameters either under basal conditions or E2 treatment, compared to its control.

\section{Discussion}

Previous studies have reported the existence of sexual dimorphism in mitochondrial biogenesis and function in rat tissues, which could be attributed to sex hormones (Justo et al. 2005a, Stirone et al. 2005, Gómez-Pérez et al. 2008, Guevara et al. 2009, Nadal-Casellas et al. 2010, 2013, Amengual-Cladera et al. 2012, Gaignard et al. 2015). In the present study, we demonstrate the involvement of E2 in maintaining energy homeostasis both in liver of OVX rats and in HepG2 cells. We also provide evidence for an active role of hepatic PGC1B in mediating the effects of E2 in mitochondrial function using HepG2 cells transfected with specific siRNA targeting PGC1A or PGC1B.

Ovariectomy-induced impairment of mitochondrial biogenesis and function led to a decline in the main markers of mitochondrial differentiation and proliferation (Tfam and mtDNA) and a decrease in oxidative capacity, as reflected by the decrease in CS activity and ATPase levels, suggesting that ovarian hormone deprivation is associated with an impairment of hepatic mitochondrial function. These results further support the role of ovarian hormones in mitochondrial function enhancement, which is in agreement with studies in rat liver showing that females exhibit greater oxidative capacity and mitochondrial differentiation compared to males (Nadal-Casellas et al. 2010). Furthermore, we meaningfully demonstrate that E2 may be a key factor in mitochondrial function, as this hormone restored hepatic mitochondrial function in OVX rats through an enhancement of mitochondrial content, which ran in parallel with improved oxidative capacity. Consistently with in vivo findings, HepG2 cells treated with E2 increased mitochondrial mass and MMP, thus increasing ATP content and levels of essential proteins involved in oxidative metabolism and mitochondrial biogenesis. OVX rats also exhibited greater hepatic oxidative stress, indicated by reduced SOD activity and higher lipid peroxidation, in agreement with previous studies (Moreno et al. 2015). Treatment with E2 increased antioxidant response, thus lowering protein oxidation damage in accordance with E2 involvement in defense against oxidative stress (Borrás et al. 2003, 2010, Viña et al. 2005).

We also reported defective glucose and lipid hepatic metabolism in OVX rats, suggested by the increase in Pepck expression and triglyceride accumulation, both of which were restored with E2 treatment. These results are in agreement with previous studies that connect estrogens with insulin sensitivity (Szmuilowicz et al. 2009, Nadal-Casellas et al. 2012), hepatic gluconeogenesis (Ahmed-Sorour \& Bailey 1981, Bryzgalova et al. 2006), and lipid metabolism (D'Eon et al. 2005, Völzke et al. 2007, Paquette et al. 2008, 2009, Suzuki \& Abdelmalek 2009). However, the higher Pepck mRNA levels in the liver of OVX rats, which point to an induction of hepatic gluconeogesis, may be attributed to posttranslational modifications of PGC1A, such as phosphorylation or deacetylation, which increase its activity (Rodgers et al. 2005, Jäger etal.2007), as levels of this coactivator remained unaltered with ovariectomy. In addition, the impaired oxidative capacity described above in combination with increased lipogenesis, such as the higher Srebp1c mRNA levels shown, caused hepatic triglyceride accumulation. In contrast, E2 replacement ameliorated mitochondrial function and biogenesis of OVX rats, accompanied by diminished lipogenesis (Srepb1c) and increased fatty acid oxidation (Ppara and Cpt1a), leading to a reduction of hepatic fat accumulation. Taken all together, E2 seems to contribute to the normal functioning of hepatocytes, as
(C) 2017 Society for Endocrinology Printed in Great Britain
Published by Bioscientifica Ltd. 
ovarian hormonal withdrawal produces an impairment of mitochondrial function and metabolism profile, which is reversed by E2 administration.

Both PGC1A and PGC1B play a pivotal role in regulating mitochondrial biogenesis and function (Scarpulla 2011). Our results suggest that PGC1B could be involved in regulating E2 effects in promoting mitochondrial function. In both in vivo and in vitro studies, the changes in mitochondrial function took place in parallel with changes in PGC1B protein levels, while those of PGC1A remained unaltered despite hormone manipulations. Thus, we aimed to look into the involvement of both PGC1A and PGC1B in the regulation of mitochondrial biogenesis and function in HepG2 cells using specific siRNA. Consistently, downregulation of PGC1B in HepG2 cells decreased TFAM and ATPase protein levels both in basal and E2-treated conditions. However, PGC1A downregulation did not diminish these markers in any condition. Our results provide strong evidence of the effects of E2 in mitochondrial function enhancement through PGC1B, as mitochondrial function did not ameliorate in hepatocytes treated with E2 when $P G C 1 B$ was knocked down. On the contrary, TFAM and ATPase protein levels were increased by E2 treatment despite PGC1A knockdown. Effects of E2 on ameliorating mitochondrial function through PGC1B rather than PGC1A have already been suggested in some mice tissues (Pardo et al. 2011, Kemper et al. 2013) and in 3T3-L1 adipocytes (Pardo et al. 2011), but as far as we are concerned it has not been yet described in liver. However, although the involvement of PGC1A in hepatic mitochondrial function and biogenesis cannot be entirely ruled out, PGC1B focusing attention on these processes has to be taken into account.

The PGC1B role on the protection of liver from steatosis has been associated with a combined and balanced effect on lipid synthesis and secretion, and on mitochondrial biogenesis and function (Sonoda et al. 2007, Chambers et al. 2012, Bellafante et al. 2013). Our study suggests that $\mathrm{E} 2$ preserved hepatocytes from steatosis through an induction of oxidative phosphorylation, fatty acid b-oxidation, and a decrease in oxidative stress, and that PGC1B may contribute to these actions by inducing mitochondrial biogenesis. Although PGC1B has been described to enhance lipogenesis through Srebp1c in response to excess energy intake (Lin et al. 2005), we found no association between higher lipogenesis and PGC1B enhancement under E2 treatment. On the other hand, a role for estrogens in the prevention of hepatic fat accumulation has been described in OVX rats through an upregulation of Srebp1c that was restored by E2 treatment (Paquette et al. 2008), so it is plausible to consider that E2 signaling may prevent hepatic lipogenesis despite PGC1B enhancement.

On the whole, our results demonstrate that $\mathrm{E} 2$ induces mitochondrial biogenesis and function in hepatocytes by means of an enhancement of mitochondrial content and oxidative capacity, which lead to lower hepatic lipid accumulation and a reduction of oxidative stress. Hence, E2 could play a pivotal role in the sexual dimorphism previously described in rat liver in mitochondrial function and biogenesis. Moreover, our study provides evidence that PGC1B may mediate hepatic mitochondrial function and be more likely to respond to hormonal milieu than PGC1A. Therefore, we suggest a novel hepatic protective role of PGC1B as a modulator of E2 effects on mitochondrial biogenesis and function supporting activation of PGC1B as a therapeutic target for hepatic mitochondrial disorders.

\section{Declaration of interest}

The authors declare that there is no conflict of interest that could be perceived as prejudicing the impartiality of the research reported.

\section{Funding}

This work was supported by Dirección General de Investigación y Gestión del Plan Nacional de Investigación Científica, Desarrollo e Innovación (SAF2010-21792) of the Spanish Government and by Comunitat Autònoma de les Illes Balears (PCTIB-31/2011, AAEE002/2012, AAEE43/2014, AAEE52/2015). B M G-P was funded by a FPU grant from the Ministerio de Educación, Cultura y Deporte (AP2012-1004) of the Spanish Government. M B-T was funded by a grant from University of Balearic Islands (07-20140303240). M S-R was funded by a grant from Balearic Islands Government (FPI11-41523224J) after being selected in the framework on an operating program co-financed by the European Social Fund.

\section{References}

Ahmed-Sorour H \& Bailey CJ 1981 Role of ovarian hormones in the long-term control of glucose homeostasis, glycogen formation and gluconeogenesis. Annals of Nutrition \& Metabolism 25 208-212. (doi:10.1159/000176496)

Amengual-Cladera E, Lladó I, Gianotti M \& Proenza AM 2012 Sex differences in the effect of high-fat diet feeding on rat white adipose tissue mitochondrial function and insulin sensitivity. Metabolism: Clinical and Experimental 61 1108-1117. (doi:10.1016/j. metabol.2011.12.016)

Bellafante E, Murzilli S, Salvatore L, Latorre D, Villani G \& Moschetta A 2013 Hepatic-specific activation of peroxisome proliferator-activated receptor $\gamma$ coactivator- $1 \beta$ protects against steatohepatitis. Hepatology 57 1343-1356. (doi:10.1002/hep.26222)

Borrás C, Sastre J, García-Sala D, Lloret A, Pallardó FV \& Viña J 2003 Mitochondria from females exhibit higher antioxidant gene expression and lower oxidative damage than males. Free Radical Biology and Medicine 34 546-552. (doi:10.1016/S0891-5849(02)01356-4)

Published by Bioscientifica Ltd. 
Borrás C, Gambini J, López-Grueso R, Pallardó FV \& Viña J 2010 Direct antioxidant and protective effect of estradiol on isolated mitochondria. Biochimica et Biophysica Acta: Molecular Basis of Disease 1802 205-211. (doi:10.1016/j.bbadis.2009.09.007)

Bryzgalova G, Gao H, Ahren B, Zierath JR, Galuska D, Steiler TL, Dahlman-Wright K, Nilsson S, Gustafsson J-A, Efendic S, et al. 2006 Evidence that oestrogen receptor- $\alpha$ plays an important role in the regulation of glucose homeostasis in mice: insulin sensitivity in the liver. Diabetologia 49 588-597. (doi:10.1007/s00125-005-0105-3)

Capllonch-Amer G, Llado I, Proenza AM, García-Palmer FJ \& Gianotti M 2013 Opposite effects of $17-\beta$ estradiol and testosterone on Mitochondrial biogenesis and adiponectin synthesis in white adipocytes. Journal of Molecular Endocrinology 52 203-214. (doi:10.1530/JME-13-0201)

Capllonch-Amer G, Sbert-Roig M, Galmés-Pascual BM, Proenza AM, Lladó I, Gianotti M \& García-Palmer FJ 2014 Estradiol stimulates mitochondrial biogenesis and adiponectin expression in skeletal muscle. Journal of Endocrinology 221 391-403. (doi:10.1530/ JOE-14-0008)

Chambers KT, Chen Z, Crawford PA, Fu X, Burgess SC, Lai L, Leone TC, Kelly DP \& Finck BN 2012 Liver-specific PGC-1beta deficiency leads to impaired mitochondrial function and lipogenic response to fastingrefeeding. PLOS ONE 7 1-9. (doi:10.1371/journal.pone.0052645)

Chen J, Gokhale M, Li Y, Trush MA \& Yager JD 1998 Enhanced levels of several mitochondrial mRNA transcripts and mitochondrial superoxide production during ethinyl estradiol-induced hepatocarcinogenesis and after estrogen treatment of HepG2 cells. Carcinogenesis 19 2187-2193. (doi:10.1093/carcin/19.12.2187)

Chrzanowska-Lightowlers ZM, Turnbull DM \& Lightowlers RN 1993 A microtiter plate assay for cytochrome c oxidase in permeabilized whole cells. Analytical Biochemistry 214 45-49. (doi:10.1006/ abio.1993.1454)

D'Eon TM, Souza SC, Aronovitz M, Obin MS, Fried SK \& Greenberg AS 2005 Estrogen regulation of adiposity and fuel partitioning: Evidence of genomic and non-genomic regulation of lipogenic and oxidative pathways. Journal of Biological Chemistry $28035983-35991$. (doi:10.1074/jbc.M507339200)

Dighe AS \& Sluss PM 2004 Improved detection of serum estradiol after sample extraction procedure. Clinical Chemistry 50 764-766. (doi:10.1373/clinchem.2003.029553)

Gaignard P, Savouroux S, Liere P, Pianos A, Therond P, Schumacher M, Slama A \& Guennoun R 2015 Effect of sex differences on brain mitochondrial function and its suppression by ovariectomy and in aged mice. Endocrinology 156 2893-2904. (doi:10.1210/en.2014-1913)

Gómez-Pérez Y, Amengual-Cladera E, Català-Niell A, Thomàs-Moyà E, Gianotti M, Proenza AM \& Lladó I 2008 Gender dimorphism in high-fat-diet-induced insulin resistance in skeletal muscle of aged rats. Cellular Physiology and Biochemistry 22 539-548. (doi:10.1159/000185538)

Guevara R, Santandreu FM, Valle A, Gianotti M, Oliver J \& Roca P 2009 Sex-dependent differences in aged rat brain mitochondrial function and oxidative stress. Free Radical Biology and Medicine 46 169-175. (doi:10.1016/j.freeradbiomed.2008.09.035)

Guo J, Duckles SP, Weiss JH, Li X \& Krause DN 2013 17ß-Estradiol prevents cell death and mitochondrial dysfunction by an estrogen receptor-dependent mechanism in astrocytes after oxygen-glucose deprivation/reperfusion. Free Radical Biology and Medicine 52 2151-2160. (doi:10.1016/j.freeradbiomed.2012.03.005)

Herzig S, Long F, Jhala US, Hedrick S, Quinn R, Bauer A, Rudolph D, Schutz G, Yoon C, Puigserver P, et al. 2001 CREB regulates hepatic gluconeogenesis through the coactivator PGC-1. Nature 413 179-183. (doi:10.1038/35093131)

Jäger S, Handschin C, St-Pierre J \& Spiegelman BM 2007 AMPactivated protein kinase (AMPK) action in skeletal muscle via direct phosphorylation of PGC-1 $\alpha$. PNAS 104 12017-12022. (doi:10.1073/ pnas.0705070104)
Justo R, Boada J, Frontera M, Oliver J, Bermúdez J \& Gianotti M $2005 a$ Gender dimorphism in rat liver mitochondrial oxidative metabolism and biogenesis. American Journal of Physiology: Cell Physiology 289 C372-C378. (doi:10.1152/ajpcell.00035.2005)

Justo R, Oliver J \& Gianotti M $2005 b$ Brown adipose tissue mitochondrial subpopulations show different morphological and thermogenic characteristics. Mitochondrion 5 45-53. (doi:10.1016/j. mito.2004.09.003)

Kemper MF, Zhao Y, Duckles SP \& Krause DN 2013 Endogenous ovarian hormones affect mitochondrial efficiency in cerebral endothelium via distinct regulation of PGC-1 isoforms. Journal of Cerebral Blood Flow and Metabolism 33 122-128. (doi:10.1038/jcbfm.2012.159)

Lin J, Tarr PT, Yang R, Rhee J, Puigserver P, Newgard CB \& Spiegelman BM 2003 PGC-1 $\beta$ in the regulation of hepatic glucose and energy metabolism. Journal of Biological Chemistry 278 30843-30848. (doi:10.1074/jbc.M303643200)

Lin J, Yang R, Tarr PT, Wu P-H, Handschin C, Li S, Yang W, Pei L, Uldry M, Tontonoz P, et al. 2005 Hyperlipidemic effects of dietary saturated fats mediated through PGC-1 $\beta$ coactivation of SREBP. Cell 120 261-273. (doi:10.1016/j.cell.2004.11.043)

Liu C \& Lin JD 2011 PGC-1 coactivators in the control of energy metabolism. Acta Biochimica et Biophysica Sinica 43 248-257. (doi:10.1093/abbs/gmr007)

Mattingly KA, Ivanova MM, Riggs KA, Wickramasinghe NS, Barch MJ \& Klinge CM 2008 Estradiol stimulates transcription of nuclear respiratory factor-1 and increases mitochondrial biogenesis. Molecular Endocrinology 22 609-622. (doi:10.1210/me.2007-0029)

Moreno FN, Campos-Shimada LB, Costa SC Da, Garcia RF, Cecchini AL, Natali MRM, Vitoriano ADS, Ishii-Iwamoto EL \& SalgueiroPagadigorria CL 2015 Vitex agnus-castus L. (Verbenaceae) improves the liver lipid metabolism and redox state of ovariectomized rats. Evidence-Based Complementary and Alternative Medicine 2015212378. (doi:10.1155/2015/212378)

Nadal-Casellas A, Amengual-Cladera E, Proenza AM, Lladó I \& Gianotti M 2010 Long-term high-fat-diet feeding impairs mitochondrial biogenesis in liver of male and female rats. Cellular Physiology and Biochemistry 26 291-302. (doi:10.1159/000320552)

Nadal-Casellas A, Proenza AM, Lladó I \& Gianotti M 2012 Sex-dependent differences in rat hepatic lipid accumulation and insulin sensitivity in response to diet-induced obesity. Biochemistry and Cell Biology 90 164-172. (doi:10.1139/o11-069)

Nadal-Casellas A, Bauzá-Thorbrügge M, Proenza AM, Gianotti M \& Lladó I 2013 Sex-dependent differences in rat brown adipose tissue mitochondrial biogenesis and insulin signaling parameters in response to an obesogenic diet. Molecular and Cellular Biochemistry 373 125-135. (doi:10.1007/s11010-012-1481-x)

Nagamine MK, da Silva TC, Matsuzaki P, Pinello KC, Cogliati B, Pizzo CR, Akisue G, Haraguchi M, Górniak SL, Sinhorini IL, et al. 2009 Cytotoxic effects of butanolic extract from Pfaffia paniculata (Brazilian ginseng) on cultured human breast cancer cell line MCF-7. Experimental and Toxicologic Pathology 61 75-82. (doi:10.1016/j.etp.2008.01.017)

Nakano K, Tarashima M, Tachikawa E, Noda N, Nakayama T, Sasaki K, Mizoguchi E, Matsuzaki M \& Osawa M 2005 Platelet mitochondrial evaluation during cytochrome c and dichloroacetate treatments of MELAS. Mitochondrion 5 426-433. (doi:10.1016/j. mito.2005.10.002)

Paquette A, Wang D, Jankowski M, Gutkowska J \& Lavoie J-M 2008 Effects of ovariectomy on PPAR $\alpha$, SREBP-1c, and SCD-1 gene expression in the rat liver. Menopause 15 1169-1175. (doi:10.1097/ gme.0b013e31817b8159)

Paquette A, Chapados NA, Bergeron R \& Lavoie J-MM 2009 Fatty acid oxidation is decreased in the liver of ovariectomized rats. Hormone and Metabolic Research 41 511-515. (doi:10.1055/s-0029-1202348)

Pardo R, Enguix N, Lasheras J, Feliu JE, Kralli A \& Villena JA 2011 Rosiglitazone-induced mitochondrial biogenesis in white adipose

Published by Bioscientifica Ltd 
tissue is independent of peroxisome proliferator-activated receptor $\gamma$ coactivator-1 $\alpha$. PLoS ONE 6 e26989. (doi:10.1371/journal. pone.0026989)

Park SH, Jeon WK, Kim SH, Kim HJ, Park DI, Cho YK, Sung IK, Sohn CI, Keum DK \& Kim BI 2006 Prevalence and risk factors of non-alcoholic fatty liver disease among Korean adults. Journal of Gastroenterology and Hepatology 21 138-143. (doi:10.1111/j.1440-1746.2005.04086.x)

Petit JM, Maftah A, Ratinaud MH \& Julien R 1992 10N-nonyl acridine orange interacts with cardiolipin and allows the quantification of this phospholipid in isolated mitochondria. European Journal of Biochemistry 209 267-273. (doi:10.1111/j.1432-1033.1992. tb17285.x)

Puigserver P, Wu Z, Park CW, Graves R, Wright M \& Spiegelman BM 1998 A cold-inducible coactivator of nuclear receptors linked to adaptive thermogenesis. Cell 92 829-839. (doi:10.1016/S00928674(00)81410-5)

Quick KL, Hardt JI \& Dugan LL 2000 Rapid microplate assay for superoxide scavenging efficiency. Journal of Neuroscience Methods $\mathbf{9 7}$ 139-144. (doi:10.1016/S0165-0270(00)00179-5)

Rodgers JT, Lerin C, Haas W, Gygi SP, Spiegelman BM \& Puigserver P 2005 Nutrient control of glucose homeostasis through a complex of PGC$1 \alpha$ and SIRT1. Nature 434 113-118. (doi:10.1038/nature03354)

Sbert-Roig M, Bauzá-Thorbrügge M, Galmés-Pascual BM, CapllonchAmer G, García-Palmer FJ, Lladó I, Proenza AM \& Gianotti M 2016 GPER mediates the effects of $17 \beta$-estradiol in cardiac mitochondrial biogenesis and function. Molecular and Cellular Endocrinology $\mathbf{4 2 0}$ 116-124. (doi:10.1016/j.mce.2015.11.027)

Scaduto RC \& Grotyohann LW 1999 Measurement of mitochondrial membrane potential using fluorescent rhodamine derivatives. Biophysical Journal 76 469-477. (doi:10.1016/S0006-3495(99)77214-0)

Scarpulla RC 2011 Metabolic control of mitochondrial biogenesis through the PGC-1 family regulatory network. Biochimica et Biophysica Acta 1813 1269-1278. (doi:10.1016/j.bbamcr.2010.09.019) Schreiber SN, Emter R, Hock MB, Knutti D, Cardenas J, Podvinec M, Oakeley EJ \& Kralli A 2004 The estrogen-related receptor $\alpha$ (ERRalpha) functions in PPAR $\gamma$ coactivator $1 \alpha$ (PGC-1 $\alpha$ )-induced mitochondrial biogenesis. PNAS 101 6472-6477. (doi:10.1073/pnas.0308686101) Shao D, Liu Y, Liu X, Zhu L, Cui Y, Cui A, Qiao A, Kong X, Liu Y, Chen Q, et al. 2010 PGC-1 beta-regulated mitochondrial biogenesis and function in myotubes is mediated by NRF- 1 and ERR alpha. Mitochondrion 10 516-527. (doi:10.1016/j.mito.2010.05.012)

Sonoda J, Mehl IR, Chong L-W, Nofsinger RR \& Evans RM 2007 PGC-1 $\beta$ controls mitochondrial metabolism to modulate circadian activity, adaptive thermogenesis, and hepatic steatosis. PNAS 104 5223-5228. (doi:10.1073/pnas.0611623104)

Stirone C, Duckles SP, Krause DN \& Procaccio V 2005 Estrogen increases mitochondrial efficiency and reduces oxidative stress in cerebral blood vessels. Molecular Pharmacology 68 959-965. (doi:10.1124/ mol.105.014662)

Suzuki A \& Abdelmalek MF 2009 Nonalcoholic fatty liver disease in women. Women's Health 5 191-203. (doi:10.2217/17455057.5.2.191)

Szmuilowicz ED, Stuenkel CA \& Seely EW 2009 Influence of menopause on diabetes and diabetes risk. Nature Reviews Endocrinology 5 553-558. (doi:10.1038/nrendo.2009.166)

Tchernof A, Poehlman ET \& Després JP 2000 Body fat distribution, the menopause transition, and hormone replacement therapy. Diabetes and Metabolism 26 12-20. (doi:DM-03-2000-26-1-1262-3636-101019-ART66)

Viña J, Borrás C, Gambini J, Sastre J \& Pallardó FV 2005 Why females live longer than males? Importance of the upregulation of longevityassociated genes by oestrogenic compounds. FEBS Letters $\mathbf{5 7 9}$ 2541-2545. (doi:10.1016/j.febslet.2005.03.090)

Völzke H, Schwarz S, Baumeister SE, Wallaschofski H, Schwahn C, Grabe HJ, Kohlmann T, John U \& Dören M 2007 Menopausal status and hepatic steatosis in a general female population. Gut $\mathbf{5 6} 594-595$. (doi:10.1136/gut.2006.115345)

Wu Z, Puigserver P, Andersson U, Zhang C, Adelmant G, Mootha V, Troy A, Cinti S, Lowell B, Scarpulla RC, et al. 1999 Mechanisms controlling mitochondrial biogenesis and respiration through the thermogenic coactivator PGC-1. Cell 98 115-124. (doi:10.1016/ S0092-8674(00)80611-X)

Received in final form 30 September 2016

Accepted 24 November 2016

Accepted Preprint published online 24 November 2016
๑) 2017 Society for Endocrinology Printed in Great Britain 